\title{
Teachers' adaptability to online education during COVID-19
}

\author{
Lorena Vulpe ${ }^{\bullet}$, Sorin Pribac ${ }^{\bullet \bullet}$
}

\begin{abstract}
Nowadays, the world is facing a pandemic that affects millions of people, leading to serious illness and social dysfunction. This poses a threat not only to the population, but also to the economic and social fields. The negative impact on these sectors is represented by economic instability and restrictions on social activities, in particular by the closure of schools and the launch of online courses that affect the educational environment. Therefore, the central theme of this research is the capacity and level of teachers in Romanian education to adapt to the COVID-19 pandemic situation. Due to the restrictions imposed to limit the spread of coronavirus, this has brought changes to the level of the education system, being performed in an online format.

The entire education system has faced difficulties such as school dropout, social inequities, lack of access to technology and the internet, lack of digital skills, transition to the online learning system, poor health conditions in school institutions, even the problem of resuming or closing the school year. Thus, in this research we analysed the level of adaptability of teachers, identifying the adaptability differences between urban and rural environments or between the levels of education at which they teach. We also identified the need to readapt the subject to be taught in the virtual environment and how much of the personal time they allocate to prepare the courses taught remotely, but above all we determined the obstacles that teachers encounter in teaching and conducting courses with students during the coronavirus period.
\end{abstract}

Keywords: COVID-19 pandemic, online education, adaptability, difficulties, school dropout

\section{Introduction}

The COVID-19 pandemic currently affects the lives of hundreds of millions of people globally, generating serious social dysfunctions, having in the same time a devastating impact on the economic and social field. Economic instability, restrictions that limit social activities - implicitly the closure of educational establishments and the conduct of courses in online format are direct results of this impact.

\footnotetext{
- Bachelor's degree-student, West University of Timisoara, Faculty of Sociology and Psychology, Timisoara, Romania, lorena.vulpe00@e-uvt.ro

- PhD Associate Professor, West University of Timisoara, Faculty of Sociology and Psychology, Sociology Department, Timisoara, Romania, sorin.pribac@e-uvt.ro
} 
With the onset of the crisis, all people involved in the educational process were affected, either the persons who are educated, educators or their families. Before the Coronavirus pandemic, education in Romania was already "in a deplorable state" due to the countless changes of ministers that were accompanied by the abandonment of the predecessor's initiatives, leading to other new reforms, which were never completed without public consultation (Hosszu \& Rughiniș, 2020). It can be stated that Romania was not at all prepared for the forced implementation of a new type of education conducted in online format given the lack of access to technology, Internet, the lack of IT knowledge of students, parents and teachers, the lack of materials adapted for online teaching and many other barriers faced by the education system. Students and teachers were in a unique situation, given the duration of the pandemic and its effects on everyday life, costs and other financial problems that directly affected the continuity of education. The pandemic has thus generated unfavourable conditions, such as school dropout, feelings of exclusion, highlighting a picture of inequity in the education system.

If initially, on March 13, 2020, 45 countries declared the closure of schools $(400$ million students being affected by this measure), between April 25-26, 2020 the number of countries with altered education system increased to 165 (over 1,37 billion of students being affected by this situation). On this occasion, the problems that already existed in education systems came to light: according to the report published by UNESCO, 1 in 10 students from disadvantaged schools have no internet connection or access to technology to conduct remote education: "only a minority of countries have the basic infrastructure to focus on the pedagogical challenges of online approaches to teaching and learning"(UNESCO, 2020B).

At the country level, Romania already faces numerous barriers in the education system in 2019: high school dropout rate (15.3\%), functional illiteracy rate $44 \%$ and especially insufficient investment in education $2.9 \%$ of gross domestic product (GDP) (Peticila, 2020). With the onset of the COVID-19 Pandemic, there were other issues that surfaced related to old education reforms that were supposed to include addressing the lack of digitalization of schools and the lack of digital skills, teacher training, curriculum adjusting, school infrastructure, educational gaps, unequal access and quality of education. (Butnaru, Nița, Anichiti, \& Brînza, 2021).

This study presents the situation at the Romanian level of the capacity of teachers to adapt to the new requirements of remote education during the COVID-19 pandemic and aims to analyse the opinions of the teachers in Romania with reference to online education and the situation imposed by the new conditions. Also, the purpose of the analysis is to highlight and raise a red flag in order to take action on the problems caused by the pandemic so that teachers are prepared and trained, having access to technology and materials adapted to the digital age in which we live, in order to finally provide a quality education.

Our research is based on determining the level of adaptability of teachers, identifying differences in adaptability between urban and rural environments, between the levels of 
education at which they teach and also between the age and seniority in education of teachers. At the same time, we want to observe the intensity of the difficulties faced by our subjects: the need to readapt the subject to be taught in the virtual environment or the obstacles they encounter in teaching and conducting courses with students. Finally, another aspect that concerned us, was the teachers' opinion on the potential of online education in the near future, as well as possible solutions for improvement.

\section{Theoretical framework.}

\section{Education during pandemic}

At the educational level, education systems are facing a crisis situation, reaching decisions to maintain the health of students and families from which they come, but also in order to stop the spread of the Covid-19 virus. Initially these decisions were recommendations: short-term closure of schools for cleaning or disinfection (especially if there were cases of infections) or social distancing strategies (postponing or cancelling conferences, gatherings, trips, physical education or meals at the school cafeteria), even precautions such as wearing masks and disinfecting hands (Centers for Disease Control and Prevention [CDC], 2021).

The scientific literature has recently been enriched with valuable contributions focusing on the impact of the pandemic on education systems worldwide (Pattison et al. 2021): studies focused on the challenges encountered in designing and implementing educational policies in the COVID-19 pandemic (Fotheringham et al. 2021); studies addressing the challenges of education in rural or peripheral areas (Campbell et al. 2021), as well as studies analysing the psychological and social impact of remote education among different school populations (Tomasik et al. 2021; Hoffman et al. 2020; Aurini \& Davies 2021). The effects of the COVID-19 pandemic on the Romanian educational system are analysed by Radu Săgeată (2020); also by Florian Bogdan and Sebastian Țoc (Bogdan \&T,oc, 2020).

During the pandemic, education ranks first as the percentage of employees working from home, given that almost all global education was conducted from home without physical participation in courses, but only online (Ahrendt, et al., 2020, p. 32).

Students who come from privileged backgrounds, who are eager and able to learn, can easily find a variant when suspending courses towards a learning alternative, due to opportunities and support by parents. Those from disadvantaged backgrounds (especially those in rural areas) often remain outside the education system when schools close. Therefore, this crisis has revealed the many inadequacies and inequities in education systems - from access to teaching materials and computers needed for online education and the support of the environment needed to focus on learning, to the imbalance between resources and needs (Schleicher, 2020, p. 4). Thus, the pandemic further exacerbates the problems that many communities already faced in terms of education. 
The ability to cope with school closure due to a pandemic differs depending on the level of development of a region or country. According to the United Nations (UN), in 2020, 86\% of primary school students dropped out of school in low-development countries, compared to only $20 \%$ in highly developed countries. For example, in most European countries, pupils and students from low socio-economic backgrounds lack opportunities such as electricity, internet, technology, curriculum, a quiet room, and even parental support during school closure (UN, 2020, p . 5).

Also, a representative study from the Romanian Institute for Evaluation and Strategy (IRES) shows that $32 \%$ of children enrolled in pre-university education do not have access to a digital device (laptop, computer, tablet) for online school, and $12 \%$ of children at country level they do not have an internet connection to be able to take part in virtual courses (IRES, 2020).

At the level of teachers there are difficulties in the technological resources, the skills to work with them and of course the reconfiguration of the subject in order to teach in online format. With the implementation of remote education, teachers do not have enough guidance, training or resources, specifically they have no support to teach in the online environment, disseminated through computer or telephone applications. Teachers around the world were not entirely ready to support continuity of learning and adaptation to the new online teaching. According to the European Commission, disadvantaged schools, from rural area or disadvantaged areas, lack, in particular, the adequate digital capacity and the necessary infrastructure to provide distance learning. Significant differences in online teaching and learning resources can also exist in both private and public environment. In most countries, private schools are familiar with the Virtual Learning Environment (VLE) and more efficient compared to public schools. However, this is not found in European countries such as Slovenia, Austria, Italy, Czech Republic, Poland, Romania, Estonia, Malta and Croatia (Milasi et al., 2020, pp. 10-11).

\section{Methodology}

The research method we used for this study is the survey: quantitative, cross-sectional, quasi-experimental and statistical method, using the questionnaire as a tool. Our main objectives are to determine the level of adaptability of teachers to online school in a crisis situation and to identify the need and time to readjust the teaching materials of the teachers in the context of online education. We also aim to identify the biggest obstacles faced by teachers in online education and highlight the adaptability differences between the teachers who teach in rural and the one from urban areas or depending on the level of education they teach.

\section{Assumptions:}

1. Between the level of adaptability of teachers to online education there are significant differences depending on the environment in which teachers works. 
2. There is an association between online education as being more beneficial for teachers teaching at an advanced level of education than other levels of education in a time of crisis.

3. There are significant differences between the level of readjustment of the subject for online teaching depending on the seniority of teachers in education.

4. There is a link between the obstacles in the preparation and online teaching process of teachers and the conduct of the class together with students.

The research tool consists of 23 questions. Half of them are opinion questions that reflect the level of adaptability of teachers and the problems and obstacles they face in online education. At the same time the last part is composed of factual questions. Thus, the questionnaire consists of closed questions, 4 semi-closed and one safe open that refers to the opinion of teachers in order to improve the online teaching activity. Also, scalar questions were used to obtain the accuracy of the respondents' opinion and a single filter question related to the level of education at which teachers teach, subsequently determining their didactic degree.

The population studied represents the totality of Romanian teachers who conducted the educational process in online format during the Coronavirus pandemic. And for the achievement of this study, the non-probabilistic sampling technique of convenience was used. This model involves the inclusion in the sample of subjects who have access to and are available to fill out the questionnaire on a voluntary basis.

Data collection took place over two months (November-December 2020). This period of application of the questionnaire is an advantage in the analysis of the results because we are before the winter vacation, in the middle of the school semester. It should be noted that the beginning of this semester was done in physical format for most schools in Romania, and in November it will be again restricted in the development of the learning process in online format. This moment was representative taking into account the return to virtual classes and the teachers who faced the obstacles of online school for the second time.

The questionnaire was disseminated both online through social media and communication platforms (e.g. Facebook, Messenger, WhatsApp as well as in the informal environment by informing the teachers and the acquaintances that could help by distributing the form, managing to accumulate a total of 437 questionnaires (of which 424 valid answers remained, having to exclude some answers in order not to limit the research and to have a study as accurate as possible).

\section{Limits:}

As a result of the data collection, we encountered difficulties such as the imbalance between the number of female and male respondents, thus preventing us from conducting statistical analyses according to gender. The discrepancy between the gender of the interviewed persons demonstrates on the other hand the reality at the educational level in Romania, namely that more than two thirds of the teachers are female. According to a report by the Ministry of Education and provided by the World Vision Romania 
Foundation "in the total teachers, women are best represented in preschool education (where 99,7\% of teachers is represented by women) and primary (90,2\%)" (Sîrbu, 2020). The fact that our research is based on 392 responses of female teachers and only 32 male responses, confirms the current situation of education in Romania and responds to the gender limit.

Another problem we faced in our research was the low number of responses to the invitation to complete the questionnaire of people who teach at the post-secondary education level ( 5 answers) and university ( 8 answers). As such, their answers were not included in our research because they are not relevant to our statistical analysis.

Another limit we have faced is the age of respondents. In our research we have groups of respondents divided by their age range. In order to analyse the level of adaptability of teachers we wanted to include as wide a range of teachers with as different ages as possible in order to achieve a more complete and truthful analysis. However, due to the unequal number of respondents across age ranges, we have not been able to have an accurate statistic.

\section{Results}

To perform this study, after data collection, and before analysing the hypotheses, we performed descriptive (frequency) analyses on certain questions to see the opinion of respondents regarding online education and how they adapted to the conditions of the virtual environment.

Out of the total number of 424 respondents, the largest number (143 responses), respectively percentage $(33,7 \%)$ is represented by a neutral statement: (a direction neither good nor wrong), for the question "please appreciate the evolution of Romanian education, taking into account the pandemic we are going through". Thus, a quarter of the teachers who completed the questionnaire have an invalid and undecided opinion related to the evolution of education. This percentage is followed by people who chose the answer "in the wrong

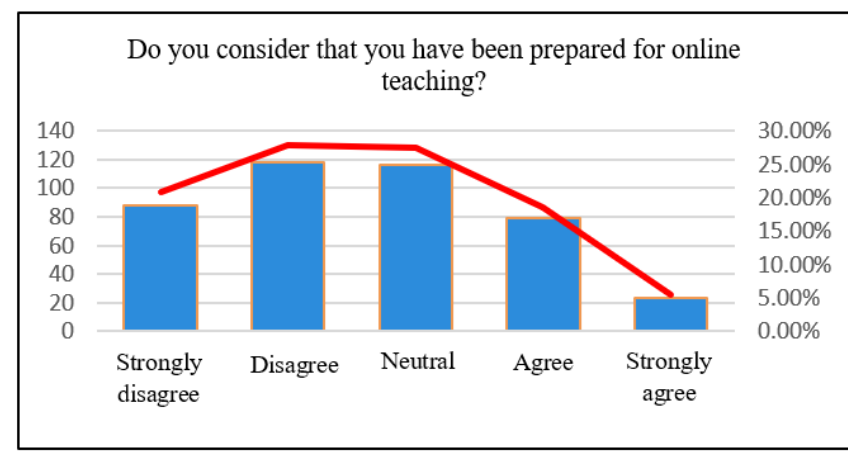

Figure 4.1. - The level of training for the online education direction": $29,5 \%$ and $24,5 \%$, respectively, of respondents who believe that education is going in the wrong and very wrong direction. Moreover, the average response rate to this question is 2,36, which demonstrates that more than half of teachers believe that Romania's education is heading in the wrong direction, and less in the right direction. For example, the percentage of people who rate the evolution of education as a good one represents an accumulated percentage of $12,3 \%$. Therefore, due to the current pandemic, teachers have a negative position considering that education will evolve in the wrong and defective direction. 
These results are closely related to the question of whether teachers were prepared for teaching in the online environment. According to figure 4.1 it can be seen that the average is slightly higher, of 2,6, which indicates that most respondents were not prepared, at most they were at an average level of preparation for online education. The highest percentage of respondents $(27,8 \%)$ claimed that they were little prepared to deal with changes in education; and the lowest percentage was given by teachers who believe that they were prepared for teaching in the online environment $(5,4 \%)$.

Following these analyses we can see that most of the teachers who claim that education will not have a very good evolution in the future, are the people who considered that they were not prepared for such a change at the educational level. For example, $44,3 \%$ of respondents who appreciate that education is heading in a very wrong direction, claim at the same time that they were not at all prepared for teaching in the virtual environment. Following a correlation between the two questions, using the Spearman test, we came to the result that there is a link statistically evidenced by the coefficient 0,33 (weak but significant correlation).

Thus, after analysing the data, we can say that those teachers who were not prepared by the online environment, believe that education will not have a good and beneficial evolution for the next generations. Therefore, teachers have a negative and critical attitude to the online environment in education, due to their insufficient preparation for virtual teaching. The fact that they have an unfavourable opinion regarding the future of education in Romania, raises a red flag about the idea of involvement and acceptance of the online environment and finally the digitalization of education.

Given the results obtained in the above, we will further study possible reasons or pretexts that lead to opposing views on online teaching. Thus, we analysed how much personal time the teachers allocate for training in teaching courses (materials,

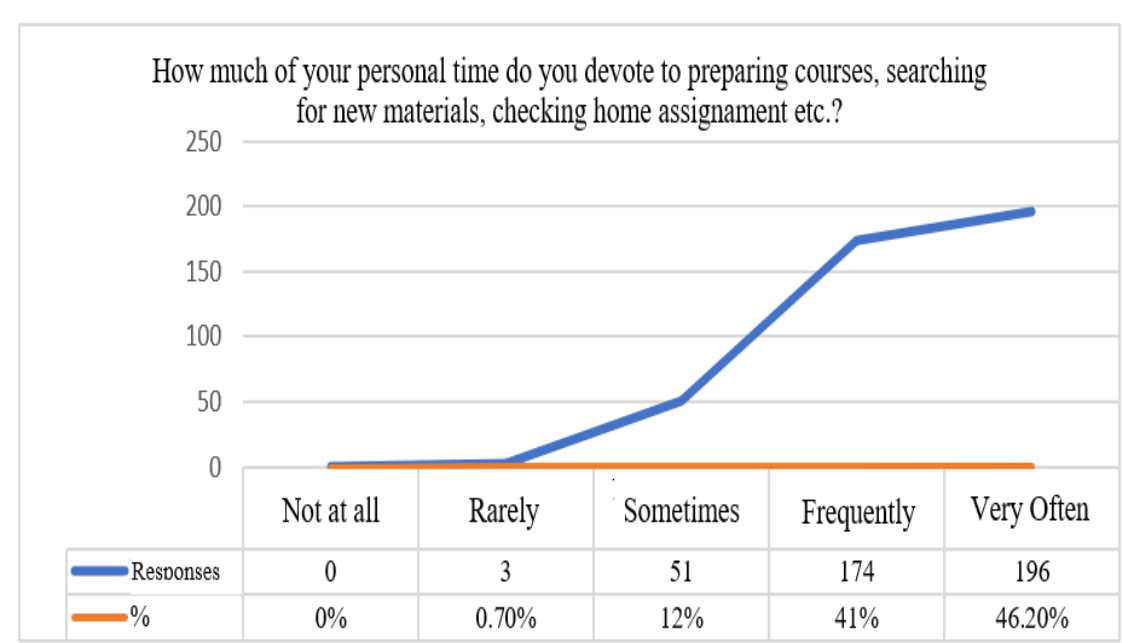

Figure 4.2 - Personal time devoted to the readjustment of courses in online education homework, assessments, etc.), trying to see if there is a balance between professional and personal life.

We find that the average of the respondents is 4,33 , a high average that reflects a lot, in fact really a lot, of personal time that teachers spends in readjusting the subject and materials for teaching in the online format. An insignificant percentage of $12 \%$ of teachers have a neutral position on this question regarding personal time and not even $1 \%$ of them 
claim that they spend very little time readjusting the discipline taught. Thus, more than 370 teachers $(77,3 \%)$ believe that they need a lot of time from their personal lives for intensive training of courses in dealing with the online environment.

These results demonstrate once again the low level of training of teachers for online teaching, having to readapt the subject and give more time for this process.

Hypothesis 1: Between the level of adaptability of teachers to online education there are significant differences depending on the environment in which they work.

Within this hypothesis we want to analyse the level of adaptability of teachers according to the environment in which they operate, given the differences in economic development between the urban and rural environment, as specified and explained by Schleicher, an imbalance of education due to the pandemic (Schleicher, 2020, p. 4). To analyse this idea we used the Mann Withney U non-parametric test, which resulted in the following data:

We wanted to analyze in detail our hypothesis that at first glance is validated. Thus, we can note that for the urban category there are 280 answers whose average rank is 224,12 . Unlike the rural category where there are 144 answers resulting in an average rank of 189,90. Therefore, the group of teachers who teach in urban areas has the higher rank average and tends to take higher values than those in rural areas.

There are significant differences in the level of adaptability of the teachers who teach in urban areas compared to those who work online in rural areas. This statement is specified by the value of the significance threshold which is less than $0,05(p=0,003)$ and also by the value of the Mann-Whitney U test $(16905,5)$. Thus, we demonstrate that urban teachers have adapted much better and more effectively to the pandemic situation with online education, compared to teachers from rural area.

Therefore, these results show us the discrepancy between the rural and the urban environment compared to the adaptability to the pandemic, respectively to the online education. This is due to the differences in the economic development of the environment in which the teaching activities take place, indicating the inequities between the environments. The Romanian rural environment is disadvantaged and has not been able to adapt so well to the online format of education, given the limited access to technology, teacher training and the virtual reality they had to face.

Hypothesis 2: There is an association between online education as being more beneficial for teachers teaching at an advanced level of education compared to other levels of education in a period of crisis.

Within this hypothesis we wanted to highlight whether there is a difference in education levels in relation to online education as a beneficial option in a time of crisis. To analyse this idea, we used The Chi-Square Association Test to see if there are significant differences between education levels. After applying the test we came to the result that affirms our hypothesis, indicated mainly by the significance threshold $(\mathrm{p}<0,05$, $\mathrm{p}=0,001)$. However, the test result does not clearly and in detail demonstrate what are the associations between the levels and the three options preferred by the teachers. In 
this context we used a recoding of the options chosen by teachers in new variables strictly on online education, physical education and hybrid education, each of them having as values "yes" and "no", respectively, representing the mention of the favourable option.

Therefore, we have chosen to re-analyse between the levels at which teachers teach and the option of online education to see if this is the most beneficial in terms of steps. We can see that there is no association between teachers at different levels and the preference of online education, indicated by the significance threshold $(\mathrm{p} 0,05, \mathrm{p}=0,75)$ and the value of the standardized adjusted interval (which must be greater than 2 or 2). ??

However, we can note that of all the respondents who preferred online education, the highest percentage is held by teachers in high school $(47,1 \%)$, while the primary level supports online education only in $14 \%$. Of the total number of respondents of 424 teachers, about three quarters (3/4) do not consider online education to be a beneficial option for a period of pandemic (303 responses against and only 121 supports online education).

In order not to leave the analysis incomplete, we repeated the same test for the other two answer variants (hybrid education and the one performed face to face). The analysis of the Chi-Square test applied for hybrid education and the levels in which teachers teach is very similar to the above, taking into account that there is no association between them $(\mathrm{p}=0,63)$. Within these statistical results, $48,8 \%$ of the total respondents who prefer this hybrid teaching option are teachers in high school education. In contrast, the highest percentage who do not support hybrid teaching is represented by teachers who teach at the secondary level $(41,4 \%)$.

Thus, we continued the analysis with the last option, that of face-to-face teaching, and we came to positive results, namely that physical education is associated with educational levels and that there are significant differences between primary and high school levels. These facts are due to the Chi-Square test which indicated a significance threshold of $p=0,000$. Of the total respondents, 252 teachers do not support physical education being a beneficial one during a pandemic period, while 172 teachers choose this option to teach in face-to-face format. Of the 252 people, $48 \%$ of them do not agree with physical education, the percentage being represented by high school education. On the contrary, $27,3 \%$ (percentage represented by the primary level) support face-to-face teaching as the best option in a period of crisis. Therefore, the level of education is associated with the preferred option of carrying out physical education in a pandemic, taking into account that there is a positive association for the primary level and a negative one for the high school level in terms of face-to-face teaching.

Therefore, the only association is between physical education and the level of primary and secondary education. Thus, the opinions of the teachers who teach at primary level are that face-to-face teaching is the most beneficial option, while high school teachers consider that hybrid education, and perhaps online education is the most appropriate in a time of crisis. 
Hypothesis 3: There are significant differences between the level of readaptability of the subject for teaching in online format according to the seniority of the teachers in education.

In order to affirm or refute this hypothesis, we used in the first phase a Kruskal-Wallis analysis, after which we noticed a disproportion of the answers, which led us to a recoding of teachers' seniority, thus performing another analysis based on Mann Whiteny $U$ test. Within this hypothesis we wanted to investigate whether there are differences between the level of readaptability of the materials according to the seniority of the teachers.

In a first stage of the hypothesis analysis we proceeded to the use of the KruskalWallis test which presented a result that affirms the idea that the readaptability of materials is done more or less, differently according to the years spent in education. From the following tables we can clearly notice the significance threshold $(p=0,29, p<0,05)$ and also the Kruskal-Wallies value (Chi-Square $[\mathrm{H}]=10,795$ with $\mathrm{df}=4$ ) which thus demonstrates that there are statistically significant differences between seniority in

Table 4.1. - The results of hypotheses

\begin{tabular}{|l|l|l|l|l|l|l|l|l|l|l|}
\hline & \multicolumn{3}{|c|}{$\begin{array}{c}\text { Analysis I - Mann Whitney } \\
\text { Test* }\end{array}$} & \multicolumn{3}{c|}{$\begin{array}{c}\text { Analysis II** -Chi- } \\
\text { square Test }\end{array}$} & \multicolumn{3}{|c|}{$\begin{array}{c}\text { Analysis III** - Mann } \\
\text { Whitney Test }\end{array}$} \\
\hline Variables & $\mathrm{N}$ & $\begin{array}{l}\text { Mean } \\
\text { Rank }\end{array}$ & $\begin{array}{l}\text { Sum of } \\
\text { Ranks }\end{array}$ & N & Percent & $\begin{array}{l}\text { Adj. } \\
\text { St }\end{array}$ & N & Mean & $\begin{array}{l}\text { Sum of } \\
\text { Ranks }\end{array}$ \\
\hline Rural area & 280 & $\mathbf{2 2 4 . 1 2}$ & 62754.50 & & & & & & \\
\hline Urban area & 144 & $\mathbf{1 8 9 . 9 0}$ & 27345.50 & & & & & & \\
\hline Online education & & & & 121 & $28.8 \%$ & 2 & & & \\
\hline Face to face education & & & & 172 & $41 \%$ & 0.1 & & & \\
\hline Hybrid education & & & & 127 & $30.2 \%$ & 1.8 & & & \\
\hline $\begin{array}{l}\text { Less than 20 years of } \\
\text { experience in education }\end{array}$ & & & & & & & 205 & 204.83 & 41991.00 \\
\hline $\begin{array}{l}\text { Over 20 years of } \\
\text { experience in education }\end{array}$ & & & & & & & 219 & 219.68 & 48109.00 \\
\hline
\end{tabular}

${ }^{*} \mathrm{p}<0.05$ - the hypothesis is validated

${ }^{* *} \mathrm{p}>0.05-$ the hypothesis is not validated

education on the level of readaptability of the subject for online courses.

Even if the significant threshold or p-value is below 0,05 , if we look at table 3.4 , we see disproportionate groups representing the seniority of the teachers. Following this finding we concluded that there is a possible influence on the result due to this inconsistency between groups. Thus, we will continue the analysis of the hypothesis in more detail, performing a recoding so that there is no longer such a large discrepancy between the groups. The subsequent tests we conducted were Mann-Whitney $U$ to examine pairwise comparisons in a post hoc manner. In this context, we find two balanced groups with fairly close ranks, but with a significance threshold higher than 0,05 $(p=0,188)$, which demonstrates that there is no difference between the two groups 
under 20 years and over 20 years of experience in education, in terms of readjusting teaching materials in online format. So our hypothesis is not validated.

Hypothesis 4: There is a link between obstacles in the preparation and online teaching process of the teachers and the conduct of the class with students.

Within this hypothesis, we wanted to investigate whether there is a link between the obstacles faced by the teachers in the training process and the difficulties encountered by them in conducting classes with students. To analyse the hypothesis we used the Pearson bivariate correlation test and created a ScatterPlot graph to show us the extent to which the two variables are influenced. To perform these analyses we recoded the two questions in the questionnaire (Q6 and Q8), so that we have two numerical variables represented by the average of the answers given by the teachers to each item of the tables.

According to the result of the bivariate correlation test, we note a significant correlation between the two variables, indicated by the value of the Pearson Correlation coefficient falling between the values +1 and $-1(R=0,719)$. Given the $R$ figure, it shows us a positive and strong relationship between the obstacles of teachers in training and online teaching and the difficulties they encounter in conducting classes with students. The significance threshold (p) is less than 0,05 alpha, which reinforces the assertion that there is a link between teacher barriers and barriers with students in online education. Thus, our hypothesis is validated taking into account the $\mathrm{R}$ and $\mathrm{p}$ values.

Next we made a Scatter Plot graph to determine the connection and its direction, that is, how the two variables influence. In our scatter plot, the points have an upward direction (they tend to form an oblique line, ascending from the value 0 to the meeting point of the 5 values of each variable). Even if there are points positioned outside the "line" or" point cloud", we can notice a dense positioning of most points from 0 at the top of the graph, which highlights

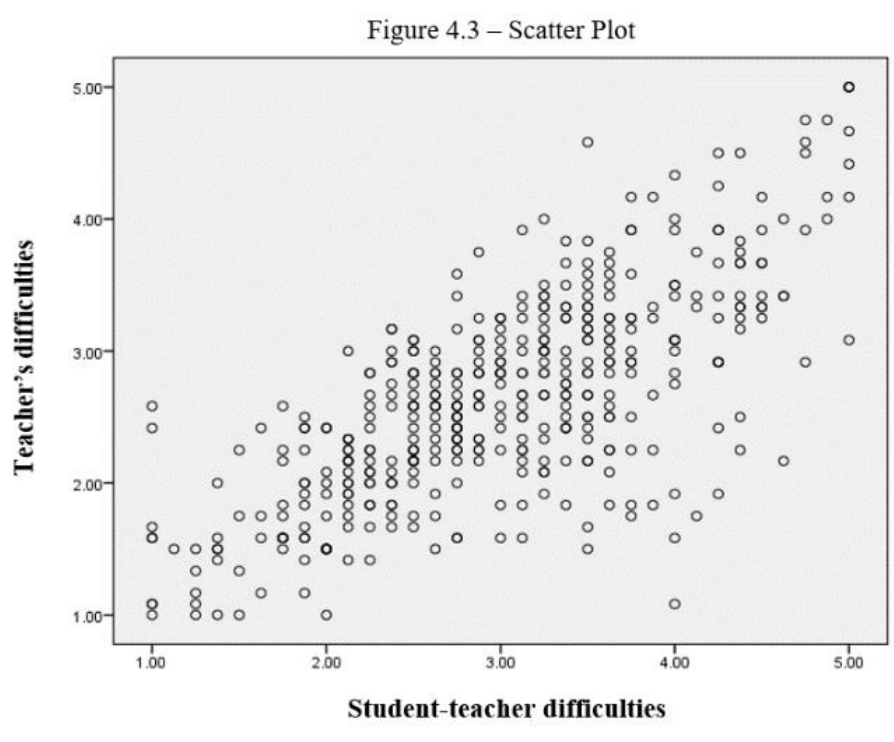
a positive correlation between variables. Taking into account the direction in which the points are heading, the two variables are directly proportional, which means that these increases of one variable are correlated with the increases of the other variable.

Therefore, we can see that there is a strong and positive link between the obstacles of teachers in preparing, namely teaching courses and conducting classes together with students. Thus, the higher the level of teaching problems in the online environment of teachers, the greater will be the difficulties of conducting virtual courses. 
Finally, we will analyse the opinion of the respondents about the potential of online education in the future, as well as the answers of teachers to the question of how teaching can be improved in the virtual environment.

Investigating teachers' opinions on the potential of online teaching, although 70 of the respondents did not want to express their opinions on this issue, we find that there are a balanced number of teachers who see a potential and those who think otherwise. The balance between the two answers tilts slightly towards a negative one, having only 5 percent more, than optimistic views regarding online education in the future.

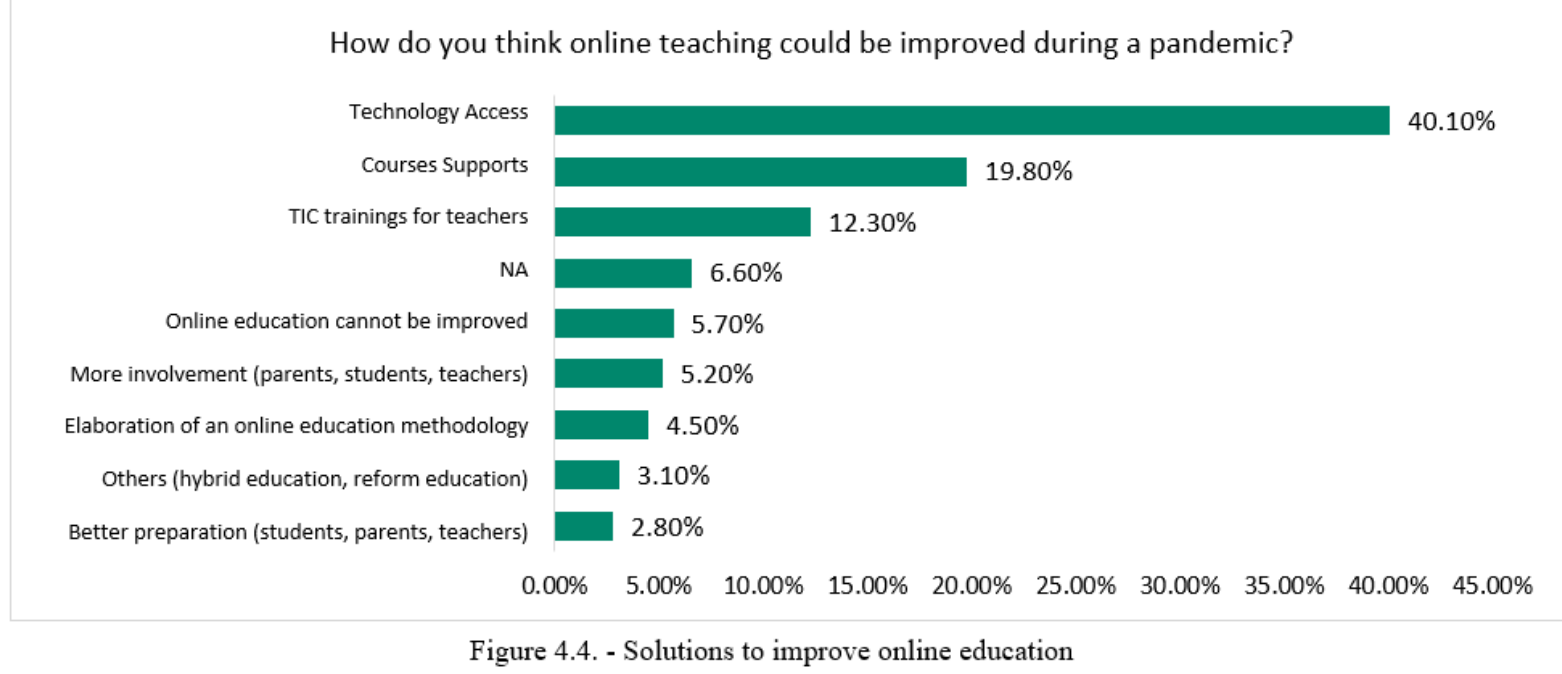

Therefore, we can say that there is not much difference between respondents in terms of the potential of virtual education being a slightly higher percentage of teachers who do not have a vision of successful online teaching (52.8\%). In this case, the answers are separate: some teachers believe that there is the possibility of the online environment in education, while others refuse this idea.

During the research, the teachers had to answer an open question regarding the improvement of the activity carried out in online format. The figure above (Figure 4.4) shows us the answers of teachers divided into categories. Thus, we observe that the most frequent response was related to the access to technology of both teachers and students (40\%), followed by access to materials (materials adapted for the online environment, assessments for teaching in the online environment, etc.) with a percentage of $21,2 \%$. Another large number of respondents (52) had the same opinion, namely that to improve the educational process carried out in the online environment requires a deeper training of teachers in the virtual environment (e.g. ICT courses, accessing platforms, etc.). The rest of the solutions for correcting problems in online teaching are stated in a percentage of $16,7 \%$. They contain statements of improvement by developing a methodology $(4,8 \%)$, by more active involvement of students and parents $(5,6 \%)$, by preparing students and parents (3\%) and others such as teaching in hybrid format or educational reform $(3.3 \%)$. Also, in a percentage of $6 \%$ teachers state that there is no way to improve and that they want to carry out the education process in physical format, and 6,6\% did not answer this question or claimed that education at the moment does not require improvement. 
Therefore, teachers tend not to have a beneficial view of online education, a statement also highlighted by the countless solutions to improve teaching in the virtual environment.

\section{Conclusions}

According to the teachers who answered our questionnaire, $66,7 \%$ of them claim that they have been able to adapt well to this pandemic situation in which education is carried out in online format. On the other hand, they also state that they needed a lot of personal time to readjust the teaching materials and were not prepared for the crisis situation that changed our lives. Teachers also believe that education is heading in the wrong direction and that they do not see any future potential in this education carried out in virtual format, expressing as solutions access to technology and teaching materials, training and instruction of teachers and even diminishing online education in favour of face-to-face education. These problems highlight the fact that although teachers have adapted, they do not support online education and some of them do not agree with the continuation of this type of education. Therefore, we can say that the adaptability of the teachers was achieved due to the mandatory and non-existence of an alternative to achieve education in a period of crisis.

Also, another dimension that we will be able to integrate in the future research can be represented by the opinions of teachers about online education carried out during the pandemic period but also their vision of an alternative to it, specifically if there will be new solutions related to an education carried out during a period of crisis.

Finally, we can conclude that after about 8 months after the pandemic caused by Coronavirus, the teachers in Romania have adapted to the crisis situation, but their attitudes towards the new education carried out in the online environment is unfavourable. Teachers believe that there is no potential and a beneficial future for this new type of education introduced out of obligation.

In conclusion, although this pandemic has surprised the entire population of the globe, none of us being prepared for such a crisis, we should learn from these landmark moments that have brought to the surface the problems facing the whole world. Thus, we believe that for a future crisis situation we should be prepared and create economic, social systems, but above all education systems that are much better prepared. It should be mentioned and emphasized the poor preparation of the educational system in Romania given the lower quality of education of the generations who learned during the Coronavirus period.

Also, at the end of this pandemic, we believe that regulations for emergency situations should be introduced, given that most teachers in Romania are not satisfied with the education carried out in the pandemic. A good part of them believe that the entire education system should be changed and adapted to the current times of the digital age, some of them proposing as a solution to improve online education a real reform of the education system. These things should raise a red flag on the responsibility that many of 
the representatives of the authorities and institutions, especially at the political level such as the Romanian government or the Ministry of education, but also the teachers in the system have on the next generations of students and students.

Thus, it is necessary to go through a crisis situation in order to notice problems such as functional illiteracy, social inequities (access to technology), poor teacher training, currently unsuitable materials and many other difficulties. Consequently, at country level we should take more responsibility for education and its level, in order to improve the education system as much as possible so that we can talk about quality education.

It should be noted, however, that although the pandemic will end and education will return to normal, the Romanian education system should integrate new teaching methods so as to reduce the discrepancy between the level of education and the needs of future generations for whom technology is not a novelty but a habit and a habit by which efficient information is obtained quickly. Thus, it can be said that the pandemic represents a test and a challenge for educational systems through which students, parents and teachers have felt the consequences of the problems of Romanian education in relation to the evolution of technology. The hope is that this attempt brought by the pandemic will lead to a future sustainable development of education through which students and teachers improve their knowledge, skills and abilities with which they will contribute to the future of society through quality education.

Finally, the Covid-19 pandemic reveals problematic aspects of education systems globally, mainly affecting the most vulnerable, those who come from poorly developed or disadvantaged environments. However, the educational community claims that it has adapted in an unexpectedly good way, laying the groundwork for a return to normal.

\section{References}

Ahrend, D., \& Mascherini, M. (2020). Living, working and COVID-19. First findings - April 2020. Eurofound. Publication Office of the European Union. Retrieved from https://www.eurofound.europa.eu/sites/default/files/ef publication/field ef document/ef2005 8en.pdf

Ahrendt, D., Cabrita, J., Clerici, E., Hurley, J., Leončikas, T., \& Mascherini, M. (2020). Living, working and COVID-19. Eurofound. Luxembourg: Publications Office of the European Union. Retrieved from https://www.eurofound.europa.eu/sites/default/files/ef publication/field ef document/ef2005 9en.pdf

Antonowicz, L., Soobrayan, P., Shabani, N., \& Fuller, S. (2020). Crearea unor sisteme de educaţie reziliente: Considerente pentru factorii de decizie de la nivel național, local și de unitate școlară. Biroul Regional UNICEF pentru Europa şi Asia Centrală. Geneva: UNICEF. Retrieved from https://www.unicef.org/romania/media/2836/file/Crearea\%20unor\%20sisteme\%20de\%20ed uca \%C5\%A3ie\%20reziliente $\% 20 \%$ C3\%AEn\%20contextul\%20pandemiei\%20de $\% 20$ COVID19.pdf

Aurini, J. \& Davies, S. (2021), COVID-19 school closures and educational achievement gaps in Canada: Lessons from Ontario summer learning research. Canadian Review of Sociology/Revue canadienne de sociologie, 58: 165- 185. https://doi-org.am.e-nformation.ro/10.1111/cars.12334; 
Bogdan, F. \& Țoc, S. (2020), Policy note: Educația în timpul pandemiei. Răspunsuri la criza nesfârșită a sistemului educaţional românesc: București;

Butnaru, G. I., Niţa, V., Anichiti, A., \& Brînza, G. (2021). The Effectiveness of Online Education during Covid 19 Pandemic-A Comparative Analysis between the Perceptions of Academic Students and High School Students from Romania. Sustainability, 13(5311). https://doi:https://doi.org/10.3390/su13095311

Campbell, K., Weingart, R., Ashta, J., Cronin, T. \& Gazmararian, J. (2021), COVID-19 Knowledge and Behavior Change among High School Students in Semi-Rural Georgia. Journal of School Health, 91: 526-534. https://doi-org.am.e-nformation.ro/10.1111/josh.13029;

CDC. (2021, Februarie 2). K-12 SCHOOLS AND CHILD CARE PROGRAMS: FAQs for Administrators, Teachers, and Parents. Centers for Disease Control and Prevention. Retrieved from https://www.cdc.gov/coronavirus/2019-ncov/community/schools-childcare/schools-faq.html

Centers for Disease Control and Prevention. (2020, Decembrie 22). Symptoms of Coronavirus. Centers for Disease Control and Prevention. Retrieved from https://www.cdc.gov/coronavirus/2019ncov/symptoms-testing/symptoms.html

Fotheringham, P., Harriott, T., Healy, G., Arenge, G. \& Wilson, E. (2021), Pressures and influences on school leaders navigating policy development during the COVID-19 pandemic. British Educational Research Journal. https://doi-org.am.e-nformation.ro/10.1002/berj.3760

Hoffman, J.A. \& Miller, E.A. (2020), Addressing the Consequences of School Closure Due to COVID-19 on Children's Physical and Mental Well-Being. World Medical \& Health Policy, 12: 300310. https://doi-org.am.e-nformation.ro/10.1002/wmh3.365

Hosszu, A., \& Rughiniș, C. (2020). DIGITAL DIVIDES IN EDUCATION. AN ANALYSIS OF THE ROMANIAN PUBLIC DISCOURSE ON DISTANCE AND ONLINE EDUCATION DURING THE COVID-19 PANDEMIC. Sociologie Românească, 18(2), 11-39. https://doi.org/10.33788/sr.18.2.1

Huber, S. G., \& Helm, C. (2020, Iunie 10). COVID-19 and schooling: evaluation, assessment and accountability in times of crises-reacting quickly to explore key issues for policy, practice and research with the school barometer. Educational Assessment, Evaluation and Accountability, 32, 237-270. doi: https://doi.org/10.1007/s11092-020-09322-y

IRES. (2020). ȘCOALA ÎN STARE DE URGENȚĂ. ACCESUL COPIILOR ȘCOLARI DIN ROMÂNIA LA EDUCATIIE ONLINE. INSTITUTUL ROMÂN PENTRU EVALUARE ȘI STRATEGIE. IRES. Retrieved from https://ires.ro/uploads/articole/ires accesul-copiilor-scolari-din-romania-la-educatieonline studiu-national aprilie-2020.pdf

Milasi, S., González-Vázquez, I., \& Fernández-Macías, E. (2020). Telework in the EU before and after the COVID-19: where we were, where we head to. Joint Research Centre. European Commission. Retrieved from https://ec.europa.eu/jrc/sites/jrcsh/files/jrc120945 policy brief_covid and telework final.pdf

Pattison, K.L., Hoke, A.M., Schaefer, E.W., Alter, J. \& Sekhar, D.L. (2021), National Survey of School Employees: COVID-19, School Reopening, and Student Wellness. Journal of School Health, 91: 376383. https://doi-org.am.e-nformation.ro/10.1111/josh.13010;

Peticila, M. (2020). Eurostat: Rata de părăsire timpurie a școlii în România s-a redus la 15,3\% în 2019, de la 19,1\% în 2015. Cea mai amplă scădere dintre statele UE. Edupedu-Ştiri la zi despre educație. Retrieved from https://www.edupedu.ro/eurostat-rata-de-parasire-timpurie-a-scolii-inromania-s-a-redus-la-153-in-2019-de-la-191-in-2015-cea-mai-ampla-scadere-dintre-statele-ue/

Săgeată, R. (2020). Școala în pandemie. Provocări și incertitudini. Cazul României. 10.13140/RG.2.2.28578.04804.

Schleicher, A. (2020). THE IMPACT OF COVID-19 ON EDUCATION. INSIHTS FROM EDUCATION AT A GLANCE 2020. OECD (Organisation for Economic Co-operation and Development). Retrieved from https://www.oecd.org/education/the-impact-of-covid-19-on-education-insights-education-at-aglance-2020.pdf 
Sîrbu, L. (2020). Statistică: Majoritatea cadrelor didactice din România sunt femei. Adevarul. Educație. Școală. Retrieved from https://m.adevarul.ro/educatie/scoala/statistica-majoritatea-cadrelordidactice-romania-femei-1 5e6231265163ec4271c37041/index.html?fbclid=IwAR3kVhVZXf9wSP80iUr8Bh6 ISqzDcLNWK24rWX6HgMBdyxsshUlIZIuG8

Thompson, G. (2020, Iunie 4). Unequal access to remote schooling amid COVID-19 threatens to deepen global learning crisis. UNICEF. Retrieved from https://www.unicef.org/press-releases/unequalaccess-remote-schooling-amid-covid-19-threatens-deepen-global-learning\# ftn1

Tomasik, M.J., Helbling, L.A. \& Moser, U. (2021), Educational gains of in-person vs. distance learning in primary and secondary schools: A natural experiment during the COVID-19 pandemic school closures in Switzerland. International Journal of Psychology, 56: 566-576. https://doi-org.am.enformation.ro/10.1002/ijop.12728

UNESCO. (2020a, 03 24). 1.37 billion students now home as COVID-19 school closures expand, ministers scale up multimedia approaches to ensure learning continuity. UNESCO -Building peace in the minds of men and women. Retrieved from https://en.unesco.org/news/137-billionstudents-now-home-covid-19-school-closures-expand-ministers-scale-multimedia

UNESCO. (2020b). Global Education Monitoring Report 2020: Inclusion and education: All means all. Paris. Retrieved from https://en.unesco.org/gem-report/report/2020/inclusion

UNESCO. (2020c). Education: From disruption to recovery. COVID-19 Impact on Education. UNESCOBuilding peace in the minds of men and women. Retrieved from https://en.unesco.org/covid19/educationresponse

UNICEF. (2020). HOW MANY CHILDREN AND YOUNG PEOPLE HAVE INTERNET ACCESS AT HOME? Estimating digital connectivity during the COVID-19 pandemic. United Nations Children's Fund and International Telecommunication Union. New York: UNICEF. Retrieved from https://www.unicef.org/media/88381/file/How-many-children-and-young-people-haveinternet-access-at-home-2020.pdf

United Nations. (2020). Education during COVID-19 and beyound. Policy Brief, United Nations. Retrieved from https://www.un.org/development/desa/dspd/wpcontent/uploads/sites/22/2020/08/sg policy brief covid-19 and education august 2020.pdf

Zhang, D., \& Livingstone, S. (2019). Inequalities in how parents support their children's development with digital technologies. Department of Media and Communications at the London School of Economics and Political Science. Londra: London School of Economics. Retrieved from https://www.lse.ac.uk/media-and-communications/assets/documents/research/preparing-fora-digital-future/P4DF-Report-4.pdf 